\title{
An Improved High-Precision Frequency Estimation Algorithm
}

\section{Shihong CHEN}

Nanjing University of Aeronautics and Astronautics https://orcid.org/0000-0002-3694-7496

\section{Minghai PAN}

Nanjing University of Aeronautics and Astronautics

Xudong WANG ( $\nabla$ xudong@nuaa.edu.cn)

https://orcid.org/0000-0003-1673-4220

\section{Research}

Keywords:

Posted Date: September 15th, 2020

DOl: https://doi.org/10.21203/rs.3.rs-28940/v2

License: (1) This work is licensed under a Creative Commons Attribution 4.0 International License. Read Full License 


\section{Abstract}

The authors have requested that this preprint be withdrawn due to author disagreement.

\section{Full Text}

The authors have withdrawn this preprint from Research Square. 